\title{
Extraprostatic extension of gleason 6 prostate cancer: single center experience
}

\author{
Gleason skor 6 prostat kanserinin ekstraprostatik yayılımı: tek merkez deneyimi
}

\author{
Onur Ceylan ${ }^{1}$, Rabia Demirtas ${ }^{1}$ \\ 1 Ataturk University, Faculty of Medicine, Department of Pathology, Erzurum, Turkey
}

Submitted: 2020-12-21

Accepted: 2021-02-08

\section{Correspondence}

Onur Ceylan

Muftusolakzade St. Samanyolu Vil. D-4.

Ylldıkent, Palandoken / Turkey

e-mail: dr.onurceylan@gmail.com

T: +90 5062773215

\section{ORCID \\ O.C. 0000-0001-7025-0521 \\ R.D. $\quad 0000-0001-8743-1847$}

\section{c) (1) $\$$}

This work is licensed under a Creative Commons Attribution-NonCommercial 4.0 International License.

\section{Özet}

Amaç: Son yllarda tedavi komplikasyonlarından dolayı gleason skor (GS) 3+3:6 prostat kanserlerinde (PK) radikal tedavi yerine klinik izlem önerilmektedir. Radikal tedavi yerine klinik izlem uygulanmasının en önemli dezavantajlarından biri düşük dereceli PK' da lokal agresif davranış görülebilmesidir. Çalışmamızda amacımız GS-6 PK' da lokal agresif davranış olarak kabul edilen ekstraprostatik yayılım (EPY) görülme oranını araştırmaktır.

Gereç ve Yöntemler: Çalışmamıza Ocak 2010-Mayıs 2019 yılları arasında bölümümüze radikal prostatektomi materyali olarak gönderilmiş prostatik adenokarsinom (GS 3+3:6) tanısı almış tersiyer patern içermeyen 119 materyal incelendi. Bu materyallerden kaçında EPY olduğu araştırıldı.

Bulgular: Çalışmamızda olguların 16 tanesinde $(\% 13,45)$ EPY tespit edildi. Bunlardan 5' inde veziküla seminalis invazyonu (pT3b), 11' inde vezikula seminalis invazyonu olmadan EPY ve/veya mesane boyun invazyonu (pT3a) izlendi.

Sonuç: GS-6 PK tanısı alan olgularımızın $\% 13,45$ ' inde EPY (pT3), \%4,2' sinde seminal vezikül invazyonu (pT3b) izlememizden dolayı GS-6 PK' nın EPY yapma olasılığının nadir olmadığını düşünüyoruz. Bu bulgularımızdan yola çıkarak klinik izlem uygulanan GS-6 PK' lı olguların EPY açısından daha dikkatli takip edilmesi gerektiğini savunuyoruz.

Anahtar Kelimeler: prostat kanseri; gleason skor; ekstraprostatik yayılım
Abstract

Objective: For Gleason Score (GS) 3+3:6 prostate cancer (PC) cases, recent guidelines recommend clinical follow-up instead of radical treatment due to complications. One of the most important disadvantages of clinical follow-up is that low-grade PC may include local aggressive behavior. Hence, our aim here was to investigate the incidence of extraprostatic extension (EPE), a local aggressive behavior, in GS6 PC cases.

Material and Methods: We examined 119 materials diagnosed with prostatic adenocarcinoma (GS 3+3:6) with no tertiary pattern and that were sent to our department as radical prostatectomy materials between January 2010 - May 2019. We investigated how many of the materials had EPE.

Results: We observed EPE in 16 (13.45\%) of our cases. 5 of the cases had vesicula seminalis invasion (pT3b) and 11 had EPE and/or bladder neck invasion (pT3a) without vesicula seminalis invasion.

Conclusion: Among our patients diagnosed with GS-6 PC, we observed EPE (pT3) in 13.45\% and vesicula seminalis invasion (pT3b) in $4.2 \%$, which suggests that the possibility of EPE is not uncommon in GS-6 PC. Based on these findings, we argue that patients with GS-6 PC under clinical follow-up should be followed more carefully for EPE.

Keywords: prostate cancer; gleason score; extraprostatic extension 


\section{INTRODUCTION}

Prostate cancer (PC) is the most common type of cancer in men worldwide, ranking in top 5 cancer types in terms of incidence and mortality rates (1). It presents significant regional differences in terms of both incidence and mortality rates (2). It is the second most common malignancy after lung cancer in our country (3). PC has a heterogeneous biological behavior pattern, which is extremely important for determining treatment protocols. Excessive treatment of non-fatal prostate cancer may impair quality of life and lead to unnecessary healthcare expenses (4). Radical prostatectomy and radiotherapy come with frequent complications like erectile dysfunction, urinary incontinence, and changes in bowel habits (4). Hence, clinical follow-up has recently become widespread in PC patients, with predictions that nearly $50 \%$ of all cases may be suitable for such an approach (5). Therefore, determining the prognostic parameters that affect survival and treatment protocols and the correlations between these prognostic parameters is very important. According to the National Comprehensive Cancer Network Guidelines, PC risk groups are determined using clinical T stage, Gleason Score (GS), and PSA level. Among these, GS is the most important prognostic indicator for PC (5).

GS is based on the architecture of the tumor. Instead of focusing on the highest graded tumor, it scores the grades of the largest and the second largest tumor areas (6). It is considered the most important prognostic parameter since it predicts the risk of recurrence and disease-specific death. GS is divided into 5 groups as GS-6, GS-7, GS-8, GS-9, and GS-10, GS-6 giving the best prognosis. Recent research reports that GS-6 PC with no tertiary pattern cannot metastasize, making active follow-up a safe and effective method (7). Selecting the most appropriate treatment method by taking into consideration the complications after radical surgery is extremely crucial. In 2014, significant changes were made to the GS system by the International Society of Urological Pathology (ISUP) (8). Since then, only a limited number of studies have investigated local aggressive behaviors such as extraprostatic extension, vesicula seminalis invasion, and distant organ metastasis in GS-6 with no tertiary pattern. Here, we aimed to contribute to the literature by investigating the possibility of local aggressive behaviors in GS-6 PC.

\section{MATERIAL AND METHODS}

We examined 191 materials that were diagnosed with prostatic adenocarcinoma after necessary histopathological examinations and were sent to the Medical Pathology Department of the Faculty as radical prostatectomy materials between January 2009 - January 2019. Of these materials, 119 cases classified as GS 3+3:6 with no tertiary pattern and accessible clinical follow-up and pathology preparations were included. Beside Hematoxylin-Eosin (H\&E) and immunohistochemical preparations, pathology diagnosis reports were obtained from the archives of our department and all cases were re-evaluated by two pathologists according to the 2014 ISUP classification. Local aggressive behaviors like EPE, vesicula seminalis invasion, and the presence or absence of distant organ metastasis were investigated. Metastasis were determined by imaging methods, clinical examination epicrisis and examination of pathological materials sent to our department in the postoperative period. The follow-up period of the patients was determined as at least 2 years. Clinical characteristics such as age and the year of the cases were obtained from the database of our hospital. Cases with unavailable clinical data and pathology preparations were excluded. Approval was obtained from the ethics committee of the Faculty of Medicine at Atatürk University (No B.30.2.ATA.0.01.00/507 dated 01.10.2020).

\section{Statistical Analysis}

The distribution of normality was assessed using D'Agostino-Pearson test. Non-parametric data was compared between groups using the Mann-Whitney $\mathrm{U}$ test. Nominal categorical variables were assessed using the Chi-squared test. A two-tailed $\mathrm{p}$ value $<0.05$ was considered statistically significant. All statistical analyses were performed using the Medcalc statistics software (MedCalc ver. 14, Ostend, Belgium).

\section{RESULTS}

Mean age was $69.2 \pm 8.25$ years, ranging from 48 to 85 years. Lymphovascular invasion was observed in 10 cases and perineural invasion was observed in 40 . 
Mean tumoral volume was $1.48 \mathrm{~cm}^{3}$, ranging from $0.012 \mathrm{~cm}^{3}$ to $14.3 \mathrm{~cm}^{3}$. No lymph node metastasis was observed in any of the cases. EPE was observed in 16 (13.45\%) of 119 cases (Figure 1). 5 cases had vesicula seminalis invasion (pT3b) and 11 had EPE and/or bladder neck invasion (pT3a) with no vesicula seminalis invasion (Figure 2, Figure 3, Figure 4). 103 cases were found to be limited in the prostate (pT2). In 18 cases, at least one invasive tumor was persistent at the surgical margin (SM). Among cases with SM positivity,
5 had proximal prostatic urethra SM, 7 had distal prostatic urethra SM, 6 had periprostatic soft tissue SM, 1 had right spermatic cord SM, and 1 had left spermatic cord SM. No distant organ metastasis was observed in any of the cases (Table).

There was no significant correlation between age and GS ( $\mathrm{p}=0.8688)$, lymph node metastasis $(\mathrm{p}=0.1992)$, or tumoral volume $(\mathrm{p}=0.4210)$. We found a significant correlation between primary tumor and tumoral volume $(\mathrm{p}<0.0001)$.

Table. Demographic and Histopathological Features of Cases

\begin{tabular}{|lc|}
\hline & Patient $(\mathbf{n}=\mathbf{1 1 9})$ \\
\hline Age & $69,2 \pm 8,25$ \\
Primary Tumor $\mathbf{~ ( \% ) ~}$ & \\
$p T 2$ & $103(86,6)$ \\
$p T 3 a$ & $11(9,2)$ \\
$p T 3 b$ & $5(4,2)$ \\
$p T 4$ & 0 \\
Lymphovascular Invasion $\mathbf{n}(\%)$ & \\
Not identified & $109(91,6)$ \\
Present & $10(8,4)$ \\
Tumor Macroscopic Diameter $(\mathbf{c m}) \mathbf{n}(\%)$ & \\
$\geq 1,48$ cm & $64(54)$ \\
$<1,48$ cm & $55(46)$ \\
EPY $\mathbf{n}(\%)$ & \\
Not identified & $103(86,6)$ \\
Present & $16(13,4)$ \\
VSI ${ }_{\mathbf{n}}(\%)$ & \\
Not identified & $114(95,8)$ \\
Present & $5(4,2)$ \\
\hline
\end{tabular}

PT: Primary Tumor, EPY: Extraprostatic Invasion, VSI: Vesicle Seminalis Invasion

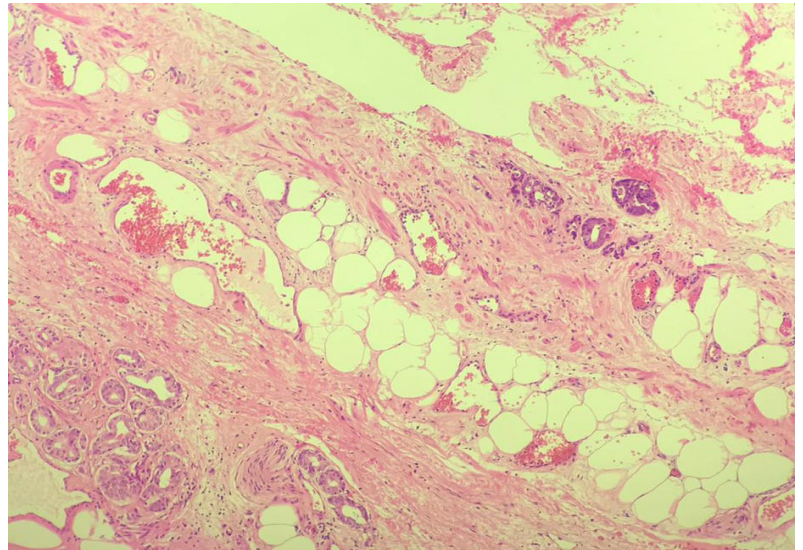

Figure 1. Areas of extraprostatic extension (H\&E) (x200)

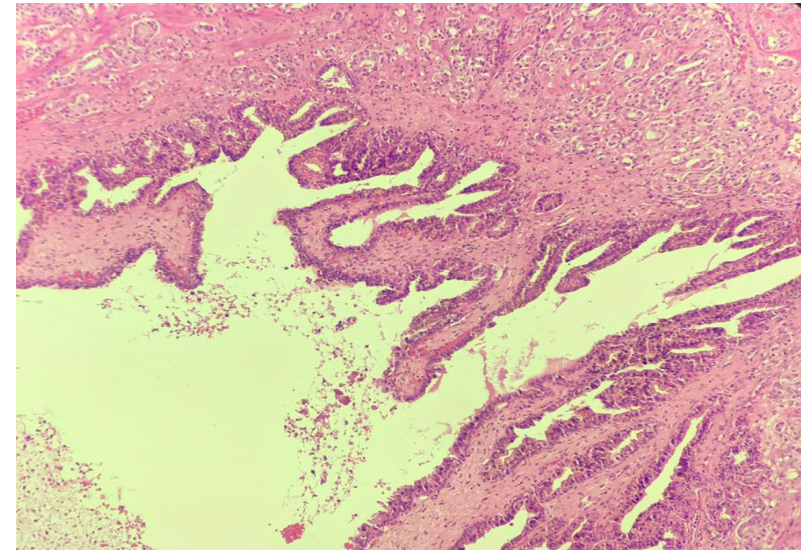

Figure 2. Areas of seminal vesicle invasion (H\&E) (x100) 


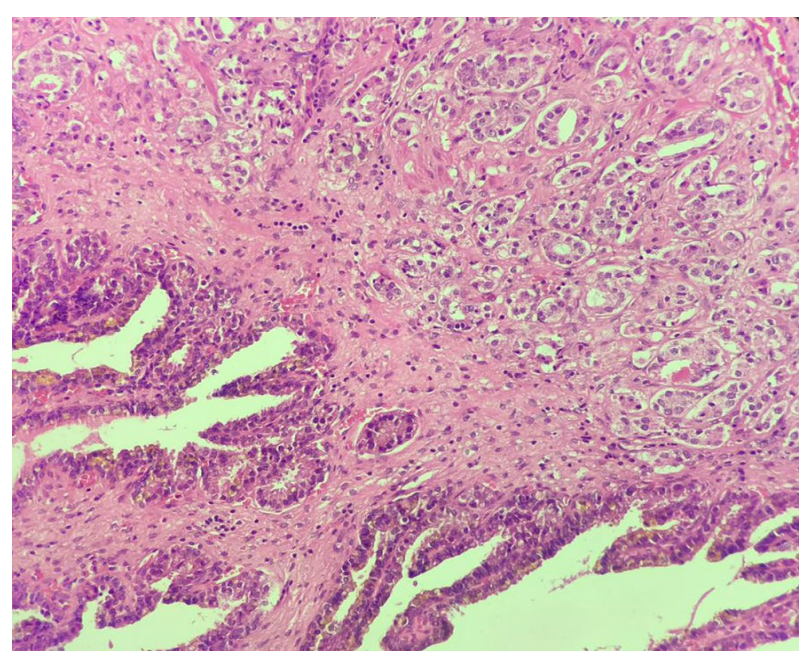

Figure 3. Areas of seminal vesicle invasion ( $\mathrm{H} \& \mathrm{E})(\mathrm{x} 200)$

\section{DISCUSSION}

PK has many different behavioral patterns determined by a number of factors, one of the most important being GS. Excessive treatment of PC with low GS can lead to severe complications, which makes selecting the correct protocol crucial (4). Studies with large samples show similarity between findings in treated and untreated patients with GS6 PC. Based on the literature, it is predicted that less than $3 \%$ of patients with GS6 PC will die in 10-15 years of follow-up, regardless of treatment (9). According to a care models study by the National Cancer Institute, nearly half of newly diagnosed patients are classified as GS6 PC, 80-90\% being treated even at ages under 75 years at diagnosis (10). However, recent studies recommend clinical follow-up rather than radical treatment in low-grade PCs due to complications. Although, there are still studies that argue otherwise (11).

Here, none of our cases had distant organ metastasis, lymph node metastasis, or PC-related mortality, although 10 cases had lymphovascular invasion. Considered a local aggressive behavior, EPE was detected in $13.45 \%$ of our cases. Of these, 5 had vesicula seminalis invasion (pT3b) and 11 had EPE and/or bladder neck invasion (pT3a) without vesicula seminalis invasion.

Hernandez et al. report no PC-related mortality or metastasis in any of their cases during a 15-year follow-up of 2551 patients with pT2 GS-6 PC (12). Sim-

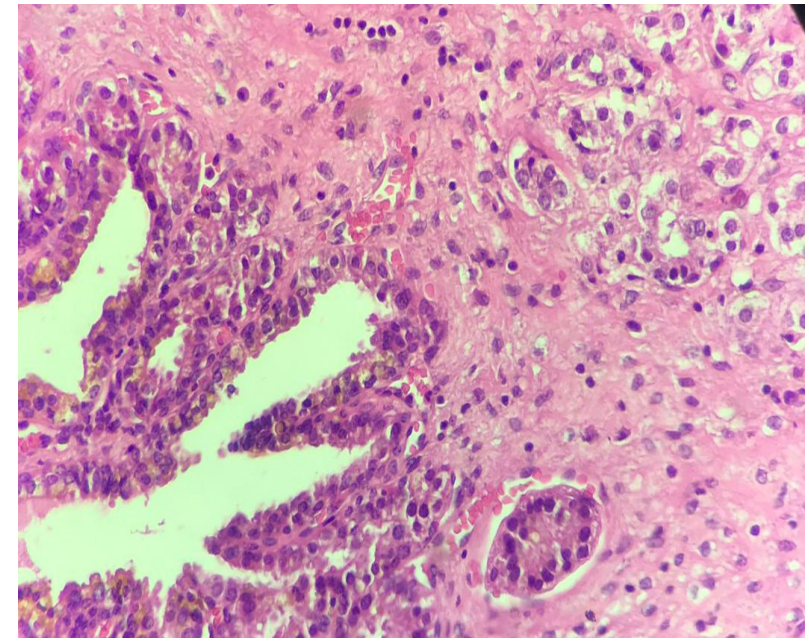

Figure 4. Areas of seminal vesicle invasion (H\&E) (x400)

ilar to Hernandez et al., we found no mortality or metastasis due to PC in any of our cases. Anderson et al. observed focal EPE in $0.28 \%$ of their cases and no vesicula seminalis invasion in a large sample of GS-6 PC patients. They also stated that they observed no lymph node metastasis or pT4 cases in any of their GS-6 PC patients. Based on these findings, they concluded that GS-6 PC rarely involved EPE, particularly not vesicula seminalis invasion (13). Hassan et al. reported that they observed EPY in $7.3 \%$ of their cases, 3.9\% being focal and $2.4 \%$ being common, and that their EPE rates were not as rare as in Anderson et al. (14). Similar to Hassan et al. we found EPE to not be uncommon in GS-6 PC cases, at almost twice the rate (13.45\%). Unlike our findings, Hassan et al. observed no vesicula seminalis invasion. We also observed no lymph node metastasis, consistent with both studies above. Alas, there is no other GS-6 PC study in the literature to compare our EPE findings with, particularly including vesicula seminalis invasion, suggesting a need for further research on this subject.

In PC, EPE is one of the most important risk factors for recurrence, which is observed in 7-10 years after radical prostatectomy in over $30 \%$ of cases with proliferation (15). Compared to focal extension, the presence of multiple foci in EPE is a much worse prognostic factor. Farchoukh et al. reported rates of no progression in 10 years as $67-69 \%$ and $36-58 \%$ for cases with 
focal and diffuse EPE, respectively. They stated that cases with multifocal extension had a significantly less 10-year follow-up with no progression (28.6\%) compared to others. They also found a much higher rate of recurrence in cases with multifocal extension (16). Similarly, Maubon, Ball et al. reported that PC cases with non-focal EPE had worse recurrence-free survival compared to focal extension cases $(17,18)$. Based on all this information, we can safely say that prognosis gets better with less EPE, highlighting the importance of timing the appropriate surgical treatment. According to our findings, it can be said that GS-6 PC cases do not involve EPE as little as thought, although claimed to rarely demonstrate EPE, and that even vesicula seminalis invasion can be observed. We believe that more care should be taken when following GS-6 PC cases, EPE should not be ignored, and early recognition of EPE during clinical follow-up can increase the success of subsequent surgical treatment.

\section{CONCLUSION}

In the current study, we observed EPE (pT3) in $13.45 \%$ of our GS-6 PC cases and even vesicula seminalis invasion (pT3b) in $4.2 \%$, suggesting that the possibility of EPE is not uncommon in GS-6 PC. Based on these findings, we argue that patients with GS-6 PC under clinical follow-up should be monitored more carefully for EPE.

\section{Acknowledgment}

No acknowledgments to declare

\section{Conflict of Interest Statement}

All authors declared that there is no conflict of interest.

\section{Financial Disclosure}

The authors declared that this study has received no financial support.

\section{Ethical Approval}

The study was approved by the Ataturk University Faculty of Medicine Clinical Research Ethics Committee (Approval number: B.30.2.ATA.0.01.00/507) (Date: 01.10.2020). The study protocol conformed to the ethical guidelines of the Helsinki Declaration.

\section{REFERENCES}

1. Ferlay J, Soerjomataram I, Dikshit R, et al. Cancer incidence and mortality worldwide: sources, methods and major patterns in GLOBOCAN 2012. Int J Cancer. 2015; 136(5):359-386.

2. Pernar CH, Ebot EM, Wilson KM, Mucci LA. The epidemiology of prostate cancer. Cold Spring Harb Perspect Med. 2018; 8(12):a030361.

3. Yilmaz B, Sarikaya D. Prostat Kanseri İnsidansı ve Risk Faktörleri. Türkiye Klinikleri Tibbi Onkoloji-Özel Konular 2017; 10:337-342.

4. Mohler JL, Armstrong AJ, Bahnson RR, et al. Prostate cancer, version 3.2012 featured updates to the NCCN guidelines. Journal of the National Comprehensive Cancer Network 2012; 10:1081-1087.

5. Rubio-Briones J, Borque A, Esteban L, et al. Preliminary results of the Spanish Association of Urology National Registry in Active Surveillance for prostate cancer. Actas Urol Esp. 2016; 40(1):3-10.

6. Samaratunga H, Delahunt B, Egevad L, Srigley JR, Yaxley J. The evolution of Gleason grading of prostate cancer. J Diagn Pathol. 2017; 12:5-11.

7. Liu J-J, Lichtensztajn DY, Gomez SL, et al. Nationwide prevalence of lymph node metastases in Gleason score $3+3=6$ prostate cancer. Pathology. 2014; 46(2):306-310.

8. Epstein JI, Egevad L, Amin MB, Delahunt B, Srigley JR, Humphrey PA. The 2014 International Society of Urological Pathology (ISUP) consensus conference on Gleason grading of prostatic carcinoma. Am J Surg Pathol. 2016; 40(2):244-252.

9. Mohler j, Bahnson RR, Boston B et al. NCCN clinical practice guidelines in oncology: prostate cancer. Practice Guideline J Natl Compr Canc Netw. 2010; 8(2):162200.

10. Hamilton AS, Albertsen PC, Johnson TK, et al. Trends in the treatment of localized prostate cancer using supplemented cancer registry data. BJU Int 2011; 107(4):576-584.

11. Carter HB, Partin AW, Walsh PC, et al. Gleason score 6 adenocarcinoma: should it be labeled as cancer? Journal of Clinical Oncology 2012;30(35):4294.

12. Hernandez DJ, Nielsen ME, Han M, et al. Natural history of pathologically organ-confined (pT2), Gleason 
score 6 or less, prostate cancer after radical prostatectomy. Urology. 2008; 72:172-176.

13. Anderson BB, Oberlin DT, Razmaria AA et al. Extraprostatic extension is extremely rare for contemporary Gleason score 6 prostate cancer. Eur Urol. 2017; 72:455-460.

14. Hassan $\mathrm{O}$, Han M, Zhou A, et al. Incidence of extraprostatic extension at radical prostatectomy with pure Gleason score $3+3=6$ (grade group 1) cancer: Implications for whether Gleason score 6 prostate cancer should be renamed" not cancer" and for selection criteria for active surveillance. J Urol. 2018; 199:1482-1487.

15. Takamatsu K, Matsumoto K, Shojo K, et al. The prognostic value of zonal origin and extraprostatic extension of prostate cancer for biochemical recurrence after radical prostatectomy. Urologic Oncology: Seminars and Original Investigations; 2019; 37(9):19-25.
16. Farchoukh L, Laframboise WA, Nelson JB, Bastacky S, Parwani AV, Dhir R. Multifocal Extraprostatic Extension of Prostate Cancer: A Third Subtype With Worse Prognosis Than Focal Prostate Cancer. Am J Clin Pathol. 2020; 153:548-553.

17. Maubon T, Branger N, Bastide C, et al. Impact of the extent of extraprostatic extension defined by Epstein's method in patients with negative surgical margins and negative lymph node invasion. Prostate Cancer Prostatic Dis. 2016; 19:317-321.

18. Ball MW, Partin AW, Epstein JI. Extent of extraprostatic extension independently influences biochemical recurrence-free survival: evidence for further pT3 subclassification. Urology. 2015; 85:161-164. 